[8] Мовчан А.П., Степанець О.В. Адаптивні та параметрично-оптимальні системи управління. Навчальний посібник .К.: НТУУ «КПІ». 2011.108 с.

\title{
References
}

[1] Melnichuk M., Blyum Ya., Dubrovin V., Targonya V., Kolomiyec Yu., Belchenko V., Bespalov I. (2011). Do pitannya obgruntuvannya ta ocinyuvannya bioklimatichnih pokaznikiv biotehnologichnih procesiv na prikladi virobnictva entomologichnogo preparatu trihogrami [To the question of substantiation and evaluation of bioclimatic indices of biotechnological processes on the example of the production of the enthologic preparation of trichogramma] Tehnika $i$ tehnologiyi APK. 8 (23). P. 34-37. [in Ukraine].

[2] Belchenko V.M., Chernova I.S. (2015). Sistema upravleniya kachestvom entomologicheskoj produkcii s ispolzovaniem informacionnyh tehnologij [Entomological product quality management system using information technologies]. Sbornik nauchnyh trudov «Zashita rastenij». Minsk. Issue 39. P. 262-267. [in Russian].

[3] Kryuchkova L.P., Borisenko, I.I. (2017). Zastosuvannya situacijnogo modelyuvannya v upravlinni tehnichnimi sistemami [Application of situational modeling in the management of technical systems]. Zv'yazok. Issue 4. P. 43-47. [in Ukraine].

[4] Mrosko Marián, Miklovičová Eva (2012). Real-time implementation of predictive control using programmable logic controllers. International Journal of Systems Applications, Engineering \& Development. Issue 1. Volume 6. P. 106113.

[5] Brakorenko A.S. (2014). Testirovanie i obespechenie kachestva programmno-tehnicheskih kompleksov na osnove ispolzovaniya virtualnyh tehnologicheskih obektov [Testing and quality assurance of software and hardware systems based on the use of virtual technological objects]. Pribory i metody izmerenij. Issue 2 (9). P. 75-80. [in Russian].

[6] Drozd O.V., Kapulin D.V. (2013). Modelirovanie i issledovanie avtomatizirovannyh sistem upravleniya i dispetcherizacii tehnologicheskih processov [Modeling and research of automated control systems and process control]. Issledovaniya naukograda. Issue 3-4 (6). P. 39-45. [in Russian].

[7] Shtovba S. D. Vvedenie v teoriju nechetkih mnozhestv i nechetkuju logiku [Introduction to the theory of fuzzy sets and fuzzy logic]. URL: http://matlab.exponenta.ru/fuzzylogic/book1/index.php

[8] Movchan A.P., Stepanec' O.V. (2011). Adaptyvni ta parametrychno-optymal'ni systemy upravlinnja. Navchal'nyj posibnyk [Adaptive and parametric-optimal control systems. Tutorial]. K.: NTUU «KPI», 108 p. [in UУДК 681.5.015

\section{МОДЕЛЮВАННЯ СЕРЕДОВИЩА ВИСТОЮВАННЯ ХЛІБОБУЛОЧНИХ ВИРОБІВ ЯК ОБ'СКТА КЕРУВАННЯ}

\author{
Драндар А.В. ${ }^{1}$, Леонтьєва I.O. ${ }^{2}$, Хобін В.А. ${ }^{3}$ \\ Одеська Національна Академія харчових технологій, м. Одеса, Україна \\ ${ }^{1}$ Магістрант, ${ }^{2}$ Аспірант, ${ }^{3}$ професор, д.т.н. \\ ORCID: ${ }^{1}$ https://orcid.org/0000-0003-4045-2266, ${ }^{2}$ https://orcid.org/0000-0003-4276-6744, ${ }^{3}$ https://orcid.org/0000-0003-0238- \\ 8371 \\ E-mail: ${ }^{1}$ drandarik@gmail.com, ${ }^{2}$ romashka.leontieva.92@ukr.net, ${ }^{3}$ khobin@onaft.edu.ua
}

Copyright (C) 2018 by author and the journal "Automation technologies and business - processes.

This work is licensed under the Creative Commons Attribution International License (CC BY).

http://creativecommons.org/licanses/by/4.0

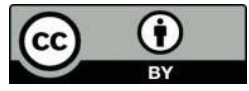

ONAFT

Open Access

DOI:

Анотація. Процес вистоювання тістових заготовок складається з багатьох фізико-механічних та біохімічних процесів, щзо ускладнює управління та отримання оптимальних показників якості на виході готового продукту. 
http://www.atbp.onaft.edu.ua/

Велика кількість регульованих змінних та інформаційних потоків впливає на хід протікання процесу дозрівання mіста. У шафах (камерах вистоювання) підтримується строгий температуро-вологісний режим. Дотримання регламенту технологічного процесу можливе лише за його автоматизації. Питання автоматизації технологічних процесів все більше постає перед сучасними підприємствами. Огляд існуючих розробок показує наявність суттєвих недоліків. На кафедрі АТП і РС розроблено новий підхід до автоматизаиії одного з процесів виробництва хліба вистоювання заготовок з тіста. Було розкрито мету технологічного процесу вистоювання тіста та виділено основні технологічні параметри, на які необхідно накласти регламент, для того щзоб якість вихідної продукції була відповідною. Враховано можливість реалізачї керуючих дій та отримання інформації про фактичні значення технологічних параметрів виходячи з можливостей сучасних технічних засобів автоматизації. Метою роботи $є$ розробка найбільш близької до процесу вистоювання тіста моделі, яка б описувала його основні властивості з можливістю їх відображення та дослідження. Модель розроблена таким чином, щяоб в подальшому ї̈ можна було б використати як основу при синтезі моделі системи автоматичного регулювання. Складено структурну схему моделі об'єкта керування. Вагомі вхідні «прямі» та «перехресні» дії математично описані статичними аперіодичними ланками другого порядку. Важливо відмітити, щзо розроблено модель id-діаграми вологого повітря та доведено ї достовірність. Представлена повна математична модель об'єкту керування $і$ зроблено висновок про можливість ї використання у подальших розробках.

Annotation. The process of standing of dough purveyances consists of many physical, mechanical and biochemical processes, that complicates a management and receipt of optimal indexes of quality on the return of the prepared product. Plenty of the managed variables and dataflows influences on motion of flowing of process of ripening of dough A strict temperature-humidity regime is carried in the cabinets (cooling rooms). The question of automation of technological processes is increasingly facing modern enterprises. An overview of existing developments shows that there are significant shortcomings. At the department of ATP and RS developed a new approach to the automation of one of the processes of production of bread putting up the blanks from the dough. The purpose of the TP of the dough was revealed and the main technological parameters for which it is necessary to impose a regulation were selected in order to ensure the quality of the output was appropriate. The possibility of implementing control actions and obtaining information on actual values of technological parameters based on the possibilities of modern technical means of automation is taken into account. The purpose of the work is to develop a model closest to the process of putting the dough, describing its main properties with the possibility of their reflection and research. The model is designed in such a way that in the future it could be used as a basis for the synthesis of the model of the automatic control system. Structural scheme of the model of the control object is made. Significant input "direct" and "cross" actions are mathematically described by static aperiodic links of the second order. It is important to note that the model of the id-diagram of the wet air has been developed and proved its reliability. The complete mathematical model of the object of management is presented and the conclusion about the possibility of its use in further development is made.

Ключові слова: автоматизація, управління, хліб, вистоювання заготовок з тіста, моделювання, об'єкт керування, id-діаграма вологого повітря.

Key words: automation, management, bread, standings of blanks, simulation, control object, id-diagram of wet air.

\section{Вступ}

Виготовлення хліба на виробництві - це досить складний глобальний процес, що складається 3 низки більш локальних процесів, одним 3 який є процес вистоювання тіста - найважливіший технологічний етап підготовки тіста безпосередньо до випічки. У процесі формування заготовок порушується пористість структури тіста і 3 нього практично повністю видаляється вуглекислий газ (оксид вуглецю), що призводить до зменшення заготовки. Під час кінцевого вистоювання відбувається інтенсивне бродіння заготовок, яке супроводжується утворенням основної частини оксиду вуглецю, в результаті - заготовки з тіста збільшуються в об'ємі. Остаточне вистоювання здійснюється в шафах різних конструкцій при температурі 32-42 градусів і відносній вологості повітря 72-85\% [1,2].

На сьогоднішній день в хлібопекарській промисловості України існує велика кількість підприємств 3 достатньо високим рівнем автоматизації. Щоб крокувати в ногу з часом і випускати якісну продукцію широкого асортименту, підприємства постійно вдосконалюють і автоматизують виробництво. Саме модернізація підприємств дозволяє багатьом гравцям хлібного ринку займати високі конкурентні позиції.

Для того, щоб максимально ефективно використати всі надані ресурси (електроенергія, пар та сировина) необхідно автоматизувати процес, враховуючи всі реальні та вагомі фактори, що впливатимуть на його хід. Створення моделі об'єкта керування є основним етапом перед розробкою моделі системи автоматичного керування, принцип реалізації якої можна застосувати на практиці. Саме представлення процесу вистоювання тіста як об’єкт керування (ОК) розглянуто в даній роботі.

Багато авторів займались моделюванням середовища технологічних процесів харчових виробництв. Найвідоміші способи моделювання харчової промисловості описані в $[3,4]$. Часто питання моделювання розглядаються в контексті розробки більш досконалих систем автоматичного управління процесом вистоювання тістових заготовок [5-8].

Суть технологічного процесу вистоювання тістових заготовок і задача ефективного управління процесом 
Метою технологічного процесу вистоювання заготовок з тіста $є$ перетворення енергетичних та матеріальних потоків у шафі остаточного вистоювання - підготовка до випічки, а саме отримання заготовок тіста, які мають відповідну пористу структуру та об’єм.

Технологічну схему процесу вистоювання тістових заготовок та регламентовані допуски для пшеничного хліба[8] (рис.1.).

Таблиця 1 - Регламентовані допуски для пшеничного хліба

\begin{tabular}{|l|c|}
\hline Регламентовані змінні на прикладі пшеничного хліба & Допуски зміни регламентованих змінних \\
\hline Температура в камері вистоювання & 38 - $39^{\circ} \mathrm{C}$ \\
\hline Вологість повітря в камері вистоювання & $78-79 \%$ \\
\hline Концентрація $\mathrm{CO}_{2}$ в камері вистоювання & $600 \mathrm{~mm}$ \\
\hline
\end{tabular}

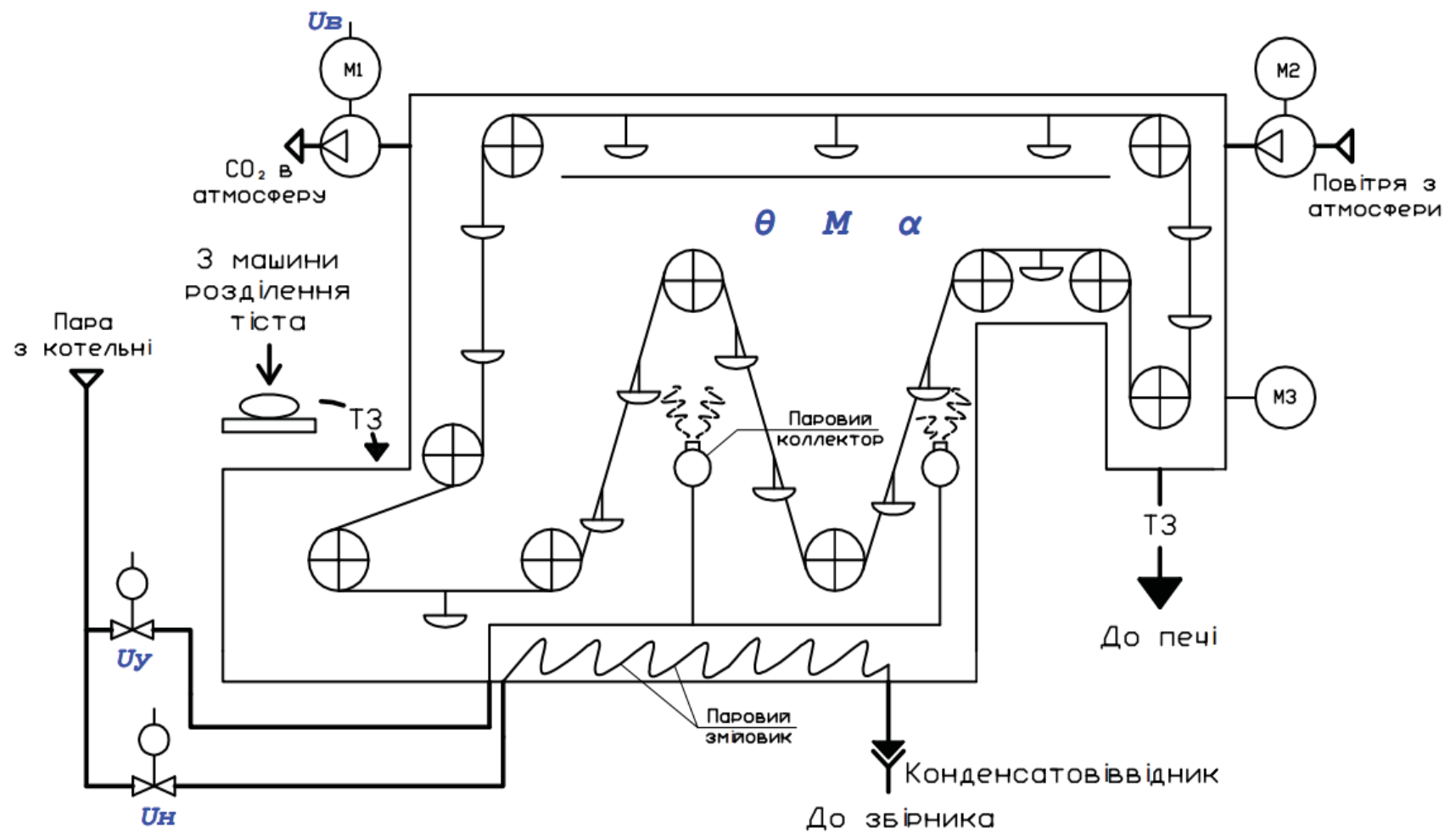

T3 - заготовки з тіста; Uн - керуюча дія на нагрів робочого середовища; Uy - керуюча дія на зволоження робочого середовища; Uв - керуюча дія на вентиляцію робочого середовища; $\theta$ - фактична температура у шафi; $M$ відносна вологість у шафі; $\alpha$ - концентраџія $\mathrm{CO}_{2}$ у шафі.

\section{Рис. 1 - Параметризована технологічна схема процесу вистоювання тістових заготовок}

Моделі технологічного процесу як об’єкта управління повинні описувати усі властивості процесу, але, як правило, відомі моделі мають формальний характер і не описують важливої фізичної закомірності - нелінійної взаємозалежності температури середовища вистоювання та іiі відносної вологості. Цю взаємозалежність відобрабражає id-діаграма (рис.3,4). Взаємозв'язком $\theta$ i М являється вологовміст середовища вистоювання d. При цьому зміна витрат зволожуючого пара (u) безпосередньо впливає саме на вологовміст.

Розробка моделі ОУ та її реалізація в середовищі імітаційного моделювання

Розроблено математичну модель процесу вистоювання хліба, в якій розглянуто залежність відносної вологості від вологовмісту та температури [9].

Представимо технологічний процес вистоювання тіста - як об’єкт керування (ОК), та складемо структурну схему його моделі (рис. 2). 


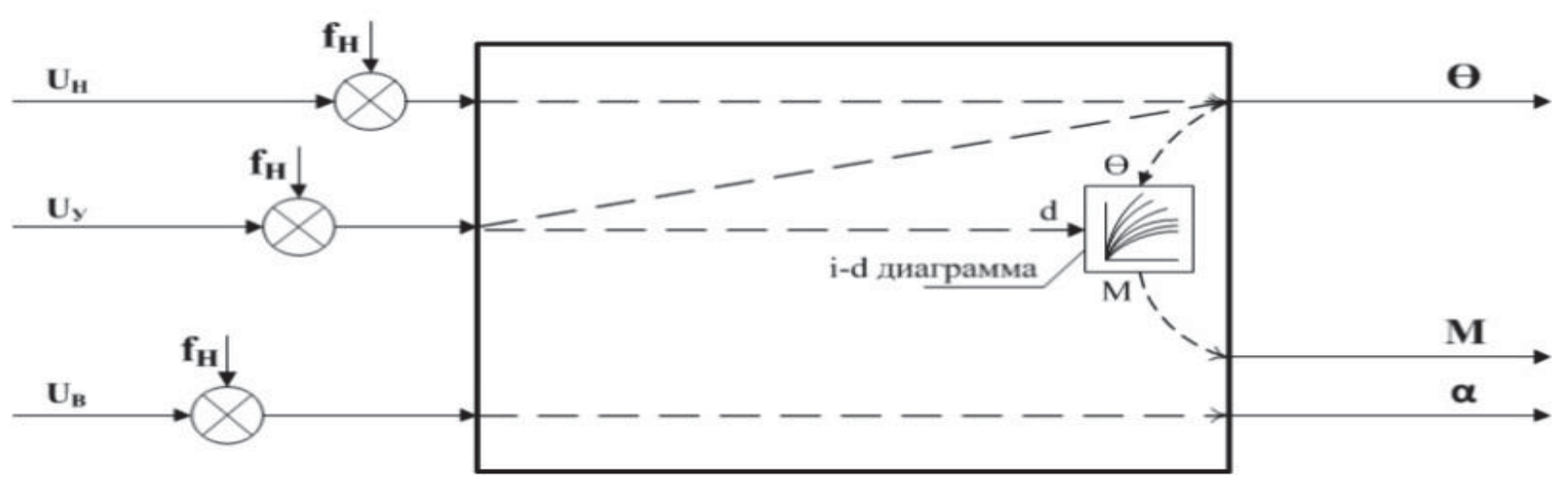

Uн - керуюча дія на нагрів робочого середовища; Uy - керуюча дія на зволоження робочого середовища; Uв керуюча дія на вентиляцію робочого середовища; $f н$ - неконтрольовані збурення; $\theta$ - фактична температура у шафі; $M$ - відносна вологість у шафi; $\alpha$ - концентрація $\mathrm{CO}_{2}$ у шафi; $d$ - вологовміст робочого середовища.

\section{Рис. 2 - Структурна схема моделі ОК}

Зв'язки на структурній схемі ОК, що відображені пунктирними лініями (рис. 2), є причино-наслідковими, наочно відтворюють ті самі вагомі вхідні «прямі» та «перехресні» дії та математично можуть бути описані як моделі диференційними рівняннями другого і більших порядків. В нашому випадку - статичними аперіодичними ланками другого порядку.

Для того, щоб отримати необхідні коефіцієнти рівнянь (параметри моделі ОК), в області робочих режимів вистоювання було проведено серію активних експериментів, суть яких полягала в подачі ступінчатого сигналу керуючої дії на окремі (по черзі) входи ОК (Uн, Uy, Uв) і зняття перехідних характеристик з усіх його виходів (Ө, М, $\alpha$ ). Після проведення параметричної лінійної ідентифікації за експериментальними перехідними характеристиками, було отримано математичні моделі каналів передачі вхідних дій об'єкта керування (табл. 2).

Таблиця 2 - Результати параметричної ідентифікації лінійної складової каналів ОУ

\begin{tabular}{|c|c|c|}
\hline \multirow{2}{*}{ Канал оу } & \multicolumn{2}{|c|}{ Модель динаміки } \\
\cline { 2 - 3 } & 1-го порядку & 2-го порядку \\
\hline$U$ - $\theta$ & $W(p)=\frac{0.2 * e^{-24.5 p}}{21.3 p+1}$ & $W(p)=\frac{0.2 * e^{-14 p}}{(15 p+1)^{2}}$ \\
\hline$U y-d$ & $W(p)=\frac{0,11 * e^{-8,6 p}}{7 p+1}$ & $W(p)=\frac{0,11 * e^{-4,1 p}}{(5,4 p+1)^{2}}$ \\
\hline$U y-\theta$ & $W(p)=\frac{0,1 * e^{-22,5 p}}{16,25 p+1}$ & $W(p)=\frac{0,1 * e^{-14,3 p}}{(11,5 p+1)^{2}}$ \\
\hline$U b-\alpha$ & $W(p)=\frac{-10 * e^{-11,9 p}}{9,7 p+1}$ & $W(p)=\frac{-10 * e^{-7,44 p}}{(6,6 p+1)^{2}}$ \\
\hline
\end{tabular}

Для моделювання процесу вистоювання тіста (моделювання ОК) було використано середовище імітаційного моделювання «Matlab». Моделювання динамічних властивостей лінійної складової ОК здійснюється на основі бібліотеки «Simulink». Моделювання нелінійної складової моделі ОК( рис.2), яка відображає його властивості здійснюється в відповідності до id-діаграми вологого повітря в камері вистоювання(рис.3). Відомо, що id-діаграма вологого повітря графічно пов'язує всі параметри, що визначають тепло-вологий стан повітря: ентальпію, вологовміст, температуру, відносну вологість, парціальний тиск водяної пари. Якщо не врахувати при моделювання фізичний закон, який вона описує, то розроблена модель не буде достовірною. 


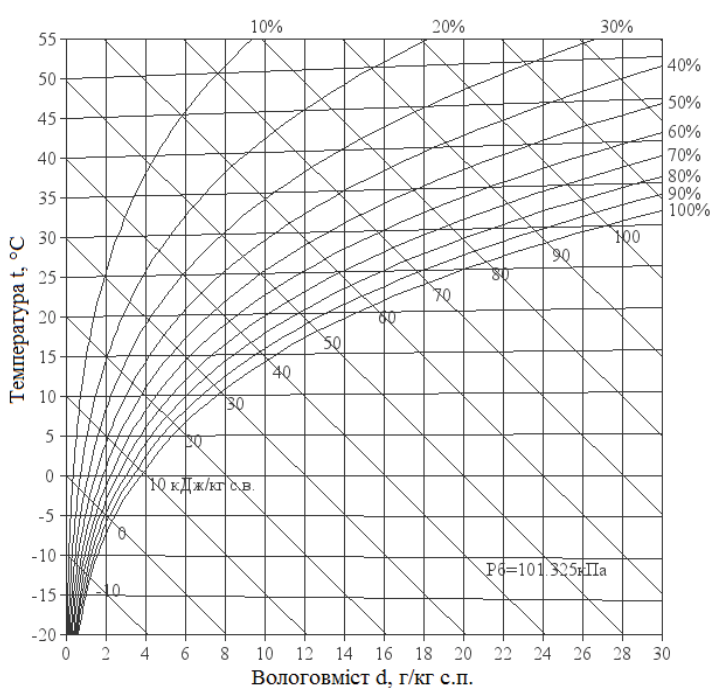

Рис. 3 - id-діаграма вологого повітря

\begin{tabular}{|c|c|c|c|c|c|c|c|c|c|c|}
\hline & \multicolumn{10}{|c|}{ Вологовміст, г/кг } \\
\hline \multirow{11}{*}{ 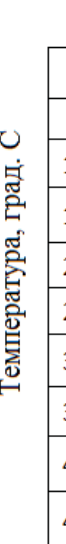 } & 2 & 4 & 6 & 8 & 10 & 12 & 14 & 16 & 18 & 20 \\
\hline & 53 & 100 & 100 & 100 & 100 & 100 & 100 & 100 & 100 & 100 \\
\hline & 38 & 75 & 100 & 100 & 100 & 100 & 100 & 100 & 100 & 100 \\
\hline & 28 & 52 & 80 & 100 & 100 & 100 & 100 & 100 & 100 & 100 \\
\hline & 20 & 38 & 57 & 76 & 94 & 100 & 100 & 100 & 100 & 100 \\
\hline & 14 & 29 & 42 & 55 & 70 & 82 & 95 & 100 & 100 & 100 \\
\hline & 10 & 20 & 31 & 40.5 & 51 & 60 & 70.5 & 80.5 & 90 & 100 \\
\hline & 8 & 16 & 23.3 & 30.5 & 38 & 46 & 53 & 60 & 68 & 75 \\
\hline & 6 & 12 & 18 & 23.5 & 29 & 35 & 40 & 45.5 & 51 & 56 \\
\hline & 4.5 & 9 & 14 & 18 & 22 & 27 & 30 & 35 & 39 & 43 \\
\hline & 3 & 7 & 10 & 14 & 17 & 20 & 24 & 27.5 & 30 & 33 \\
\hline
\end{tabular}

Рис. 4 - Вміст блоку «Look - Up Table 2D»

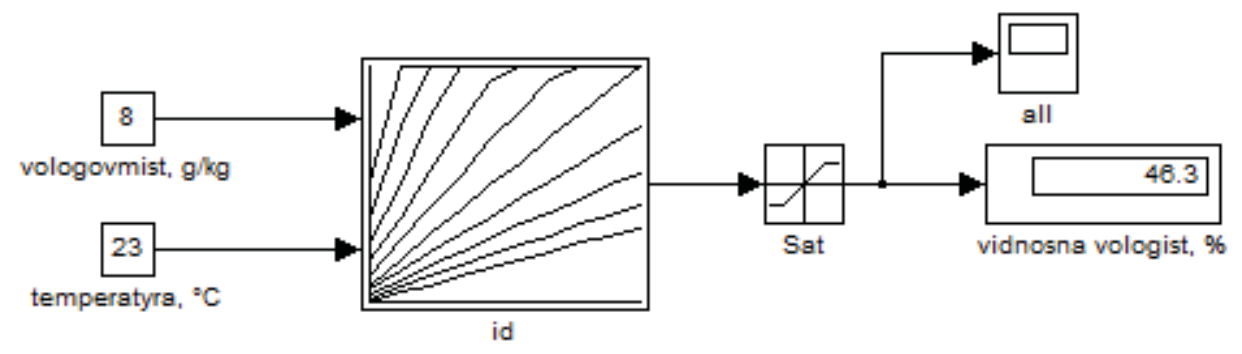

Рис. 5 - Модель id- діаграми

Для імітації фізичного закону, суть якого відображена на id- діаграмі, було використано блок $з$ стандартної бібліотеки Simulink «Look - Up Table 2D». Дані у блоці зберігаються у вигляді таблиці (рис. 3) та були введені методом визначення відносної вологи по id-діаграмі. 3 рис. 3-4 видно, що для кожного значення температури (в межах $\left.0-45^{\circ} \mathrm{C}\right)$ та вологовмісту (в межах $2-20$ г/кг) існує відповідне значення відносної вологості $(0-100 \%)$. Важливо відмітити, що блок «Look - Up Table 2D» може інтерполювати та екстраполювати значення. В даному випадку функція інтерполювання відіграє дуже важливу роль, адже в процесі моделювання в блок можуть записуватись значення температури та вологовмісту, що не записувались в таблицю (наприклад, значення температури $15 . . .20{ }^{\circ} \mathrm{C}$ ). Функцію екстраполювання необхідно обмежити, бо зрозуміло, що відносна волога не може бути більш, ніж 100 \%. Враховуючи цю особливість, в модель діаграми на виході встановимо обмеження 0 - 100. Модель діаграми зображена на рис. 5. В першому експерименті розмножимо модель діаграми та подамо на кожну копію блока одне і теж саме лінійно зростаюче значення температури (від 0 до $\left.45{ }^{\circ} \mathrm{C}\right)$, але різні значення вологовмісту $(3,6$ г/кг; 7,2 г/кг; 10,8 г/кг; 14,4 г/кг; 18 г/кг). В другому експерименті вирішимо зворотну задачу. Подамо на кожну копію блока одне й те саме лінійно наростаюче значення вологовмісту (від 0 до 20 г/кг), але різні значення температури $\left(9^{\circ} \mathrm{C} ; 18^{\circ} \mathrm{C} ; 27^{\circ} \mathrm{C} ; 36^{\circ} \mathrm{C}\right.$; $\left.45^{\circ} \mathrm{C}\right)$.

\section{Результати}

Для підтвердження адекватності імітаційної моделі, яка відповідає реальній моделі id-діаграми, було проведено декілька взаємозалежних імітаційних експериментів.

В першому експерименті - змінюється температура, а сталим залишається значення вологовмісту. Результати першого експерименту приведено на рис. 6 a.

В другому експерименті лінійно наростаюче змінюється значення вологовмісту, але при сталій температурі. Результати другого експерименту приведено на рис. $6 б$. 

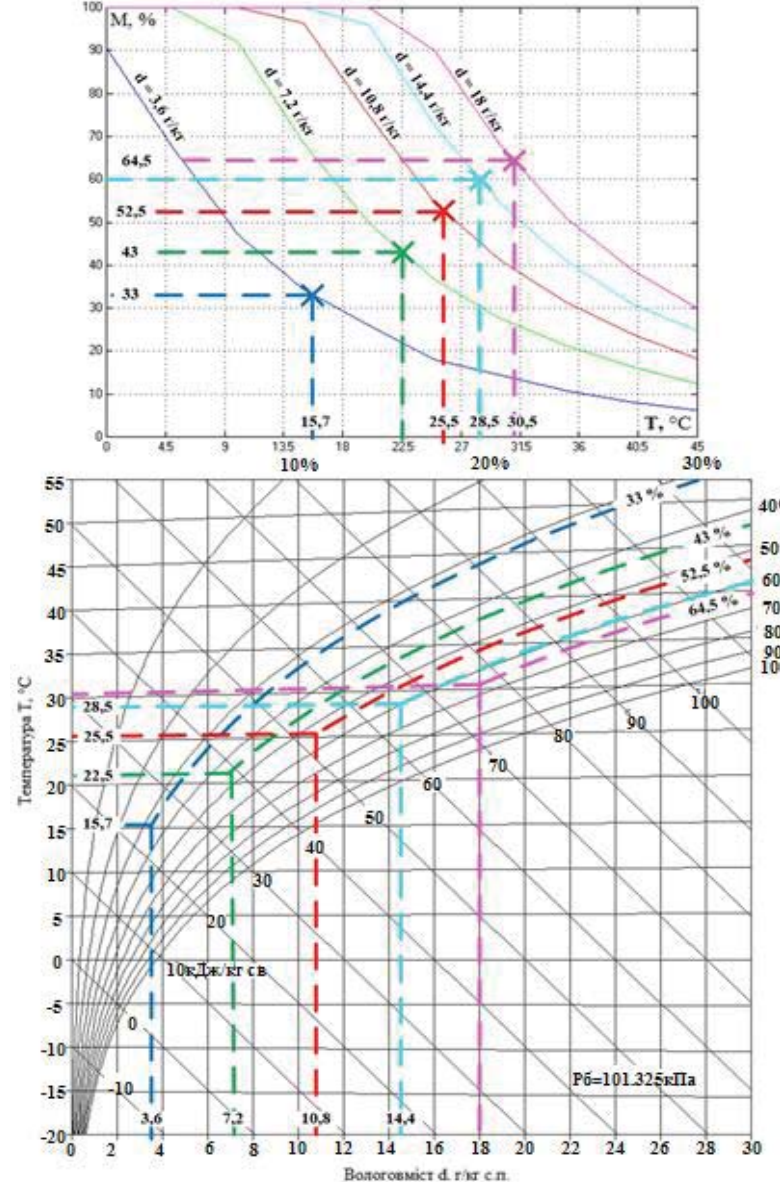
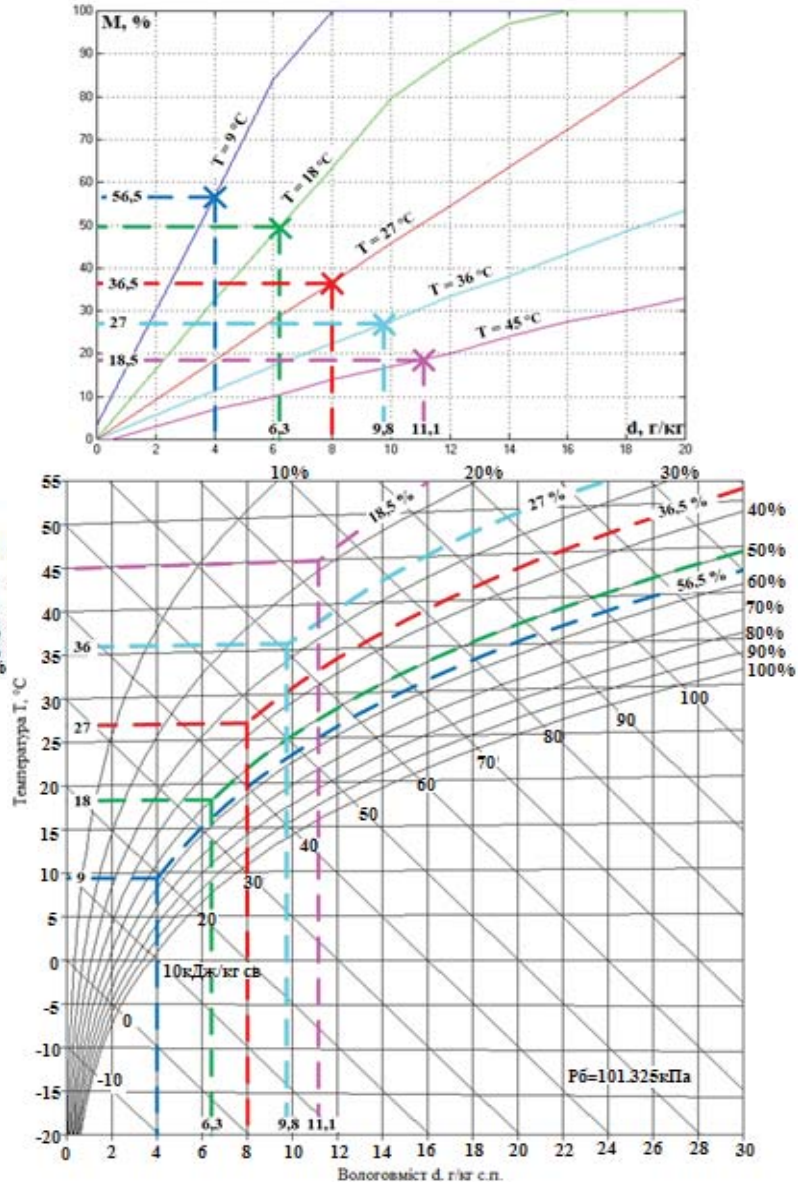

Рис. 6a, 6 - Імітація результатів експериментів по підтвердженню адекватності імітаційної моделі іd-діаграми

Як результат плідної роботи, було зареєстровано перехідні характеристики (ПХ) повної моделі ОК за всіма трьома виходами $(\Theta, \mathrm{M}, \alpha)$ в залежності від значення входів (Uн, Uy, Uв) ( рис. 7-10).

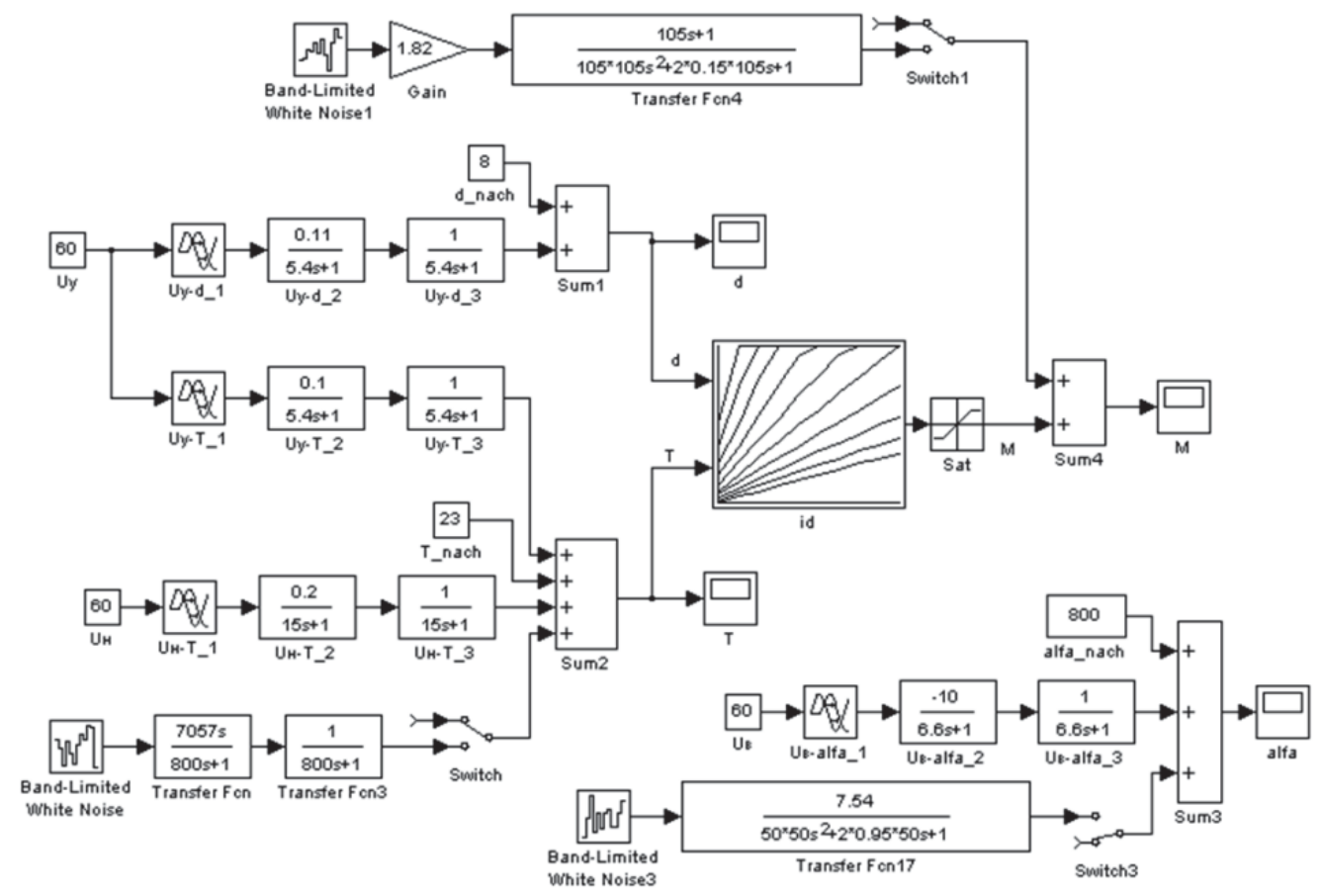

Рис. 7 - Повна модель ОК 


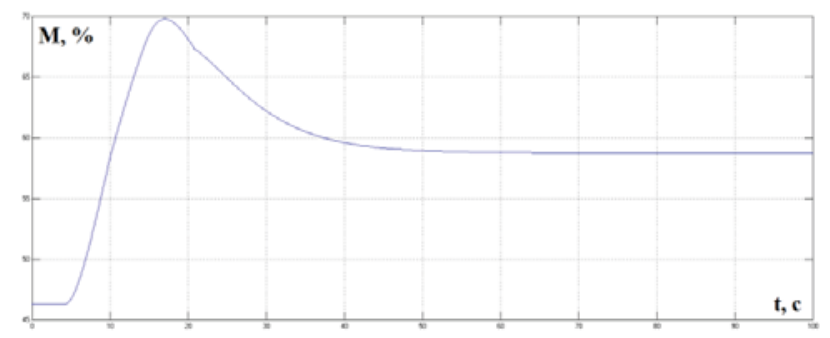

Рис. 8 - ПХ за каналом Uy-M $(\mathrm{Uy}=60 ; \mathrm{Uy}=0 ; \mathrm{UB}=0)$

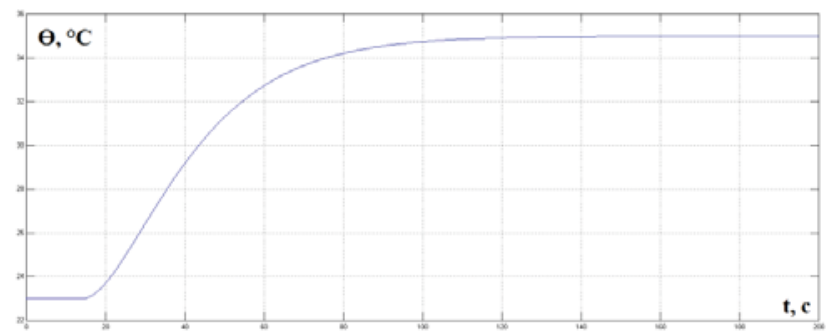

Рис. 9 - ПХ за каналом Uн-Ө $(\mathrm{Uy}=0 ; \mathrm{Uy}=60 ; \mathrm{UB}=0)$

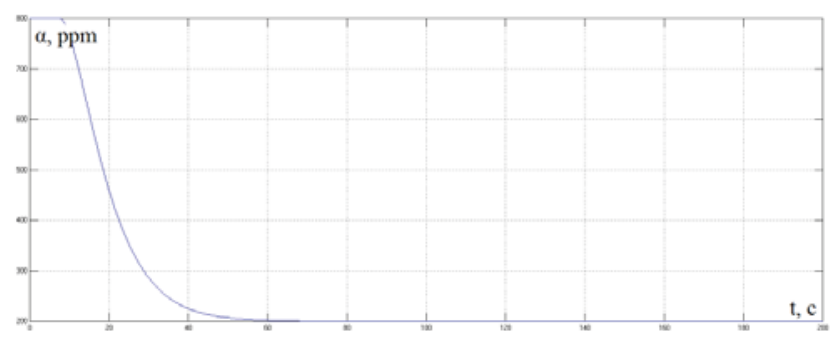

Рис. 10 - ПХ за каналом Uв- $\alpha\left(\mathrm{Uy}=0 ; \mathrm{Uy}=0 ; \mathrm{UB}_{\mathbf{B}}=60\right)$

\section{Висновки}

1) Використання розробленої нелінійної моделі середовища вистоювання хлібобулочних виробів більш адекватно відображає реальні властивості середовища вистоювання тістових заготовок.

2) Підвищення ефективності процесу вистоювання хлібобулочних виробів, зокрема оптимізація параметрів середовища вистоювання, потребує розробки САР, що забезпечить високу динамічну точність дотримання робочих режимів середовища ОК. Отже, розглянута модель зможе стати основою для розробки такої САР.

\section{Перелік використаних джерел}

[1] Л. Ф. Зверев, З. С. Немцова "Технология и техно-химический контроль хлебо-пекарного производства"

[2] Вистоювання тіста [Електронний ресурс] - Режим доступу до ресурсу: http://hlebopekar.com/stati/rasstoika_testa.

[3] М.В. Остапчук Основи математичного моделювання процесів харчових підприємств, Київ, 1991 р.

[4] Патент України №44182 / Кугут М. В.; МПК (2009) А21С 14/00; номер заявки: u200903015; дата подання заявки: 30.03.2009; дата з якої є чинними права на корисну модель: 25.09.2009; публікація відомостей про видачу патенту: 25.09.2009, Бюл. №18, 2009p.; URL: http://uapatents.com/2-44182-sposib-avtomatichnogo-keruvannyaprocesom-rozstoyuvannya-tista.html

[5] Патент України №31061 / Хобін В. А., UА, Котлик О. С.; МПК (2006) А21C 14/00; номер заявки: и200712788; дата подання заявки: 19.11.2007; дата 3 якої є чинними права на корисну модель: 25.03.2008; публікація відомостей про видачу патенту: 25.03.2008, Бюл.№6, 2008p.; URL: http://uapatents.com/2-31061-sposibavtomatichnogo-keruvannya-procesom-rozstoyuvannya-tista.html

[6] Патент України №71747 / Янковенко В. В., Сичук Л. М., UA; МПК (2012.01) A21C 13/00; номер заявки: и 2012 00280; дата подання заявки: 10.01.2012; дата з якої є чинними права на корисну модель: 25.07.2012; публікація відомостей про видачу патенту: 25.07.2012p., Бюл.№ 14; URL: http://uapatents.com/5-71747-sposibavtomatichnogo-keruvannya-procesom-rozstijjki-tista-pri-virobnictvi-khliba.html

[7] Патент України №53004 / Таран С. Г., Левінський В. М.; МПК (2009) А21С 13/00; номер заявки: и201001271; дата подання заявки: 08.02.2010; дата з якої є чинними права на корисну модель: 27.09.2010; публікація відомостей про видачу патенту: 27.09.2010, Бюл.№ 18, 2010p.; URL: http://uapatents.com/3-53004-sposibavtomatichnogo-keruvannya-procesom-rozstijjki-tista-pri-virobnictvi-khliba.html. 
[8] Леонтьєва, I., \& Хобін, В. (2018). Процес вистоювання тістових заготовок як об'єкт управління. Аutomation of Technological and Business Processes, 10(3), 19-22. https://doi.org/10.15673/atbp.v10i3.1085.

[9] Драндар А.В. Автоматизація керування процесом розстоювання тіста в камері КР-303-GO1 на підприємстві “Одеський коровай““ (Рукопис). - Одеса: ОНАХТ. - 120с.

\section{References}

[1] L. F. Zverev, Z. S. Nemtsov "Technology and techno-chemical control of bread and bakery production".

[2] Standing Test [Electronic Resource] - Resource Access Mode: http://hlebopekar.com/stati/rasstoika_testa.

[3] M.V. Ostapchuk Fundamentals of Mathematical Modeling of Processes of Food Enterprises, Kyiv, 1991.

[4] Patent of Ukraine №44182 / Kugut M.V ; IPC (2009) A21S 14/00; application number: u200903015; Date of application: 30.03.2009; the date from which the rights to the utility model are valid: 09/25/2009; publication of information on the issuance of a patent: September 25, 2009, Bull. №18, 2009; URL: http://uapatents.com/2-44182sposib-avtomatichnogo-keruvannya-procesom-rozstoyuvannya-tista.html

[5] Patent of Ukraine №31061 / Khobin VA, UA, Kotlik O. S .; IPC (2006) A21S 14/00; application number: u200712788; Date of application: 19.11.2007; the date from which the right to utility model is valid: 25.03.2008; publication of information on the issuance of a patent: March 25, 2008, Bul. \# 6, 2008; URL: http://uapatents.com/2-31061-sposibavtomatichnogo-keruvannya-procesom-rozstoyuvannya-tista.html

[6] Patent of Ukraine №71747 / Jankovenko V.V., Sychuk L.M., UA; IPC (2012.01) A21S 13/00; application number: u 2012 00280; Date of application: 10.01.2012; the date from which the right to utility model is valid: 25.07.2012; publication of information on the issuance of a patent: 25th of July, Bulletin No. 14; URL: http://uapatents.com/571747-sposib-avtomatichnogo-keruvannya-procesom-rozstijjki-stita-pri-virobnictvi-khliba.html

[7] Patent of Ukraine №53004 / Taran Ye.G., Levinsky V.M .; IPC (2009) A21C 13/00; application number: u201001271; Date of application: 08.02.2010; the date from which the rights to the utility model are valid: 27.09.2010; publication of information on the issuance of a patent: September 27, 2010, BUL \# 18, 2010; URL: http://uapatents.com/3-53004sposib-avtomatichnogo-keruvannya-procesom-rozstijjki-stita-pri-virobnictvi-khliba.html

[8] Leontieva I., \& Khobin V. (2018). The process of putting up the dough blanks as an object of management. Automation of Technological and Business Processes, 10 (3), 19-22. https://doi.org/10.15673/atbp.v10i3.1085.

[9] Drandar AV Automation of the control of the process of settling the dough in the camera KP-303-GO1 at the enterprise "Odessa Koraw" (Manuscript). - Odessa: ONACHT. - 120s. 